\title{
Hubungan Tindakan Pemberantasan Sarang Nyamuk (PSN) dengan Keberadaan Jentik Vektor Chikungunya di Kampung Taratak Paneh Kota Padang
}

\author{
Mutia Dwi Putri ${ }^{1}$, Adrial $^{2}$, Lili Irawati ${ }^{3}$
}

\begin{abstract}
Abstrak
Kampung Taratak Paneh merupakan daerah yang paling banyak terjadi kasus Chikungunya pada tahun 2012 (45 kasus). Penyebaran Chikungunya dipengaruhi faktor lingkungan dan tindakan Pemberantasan Sarang Nyamuk (PSN). Tujuan penelitian ini adalah melihat hubungan PSN terhadap keberadaan larva vektor Chikungunya. Penelitian ini adalah analitik dengan desain cross sectional study. Penelitian dilaksanakan di Kampung Taratak Paneh dengan jumlah subjek sebanyak 87 orang. Subjek diambil dengan metode proporsional simple random sampling. Data disajikan dalam bentuk tabel distribusi dan dianalisis dengan uji chi square. Hasil penelitian ini menunjukkan bahwa ada hubungan antara tindakan PSN dengan keberadaan jentik $(p=0,000)$. Terdapat hubungan yang bermakna antara menguras TPA untuk keperluan mandi $(p=0,029)$ dan keperluan rumah tangga $(p=0,038)$, menutup TPA setiap kali digunakan $(p=0,013)$, mengubur barang bekas $(p=0,034)$, menabur bubuk abate $(p=0,001)$, dan membersihkan talang air $(p=0,000)$ terhadap keberadaan jentik vektor Chikungunya. Tidak terdapat hubungan antara tindakan memelihara ikan pemakan jentik $(p=0,760)$, pencahayaan dan ventilasi yang cukup ( $p=0,053)$, menggantung pakaian di dalam kamar $(p=0,068)$, memasang kawat kasa $(p=0,274)$, membersihkan pot/vas bunga berisi air/tempat minum burung $(p=0,915)$, menggunakan kelambu $(p=0,619)$, menggunakan obat anti nyamuk $(p=0,209)$ dan menutup lubang pohon $(p=0,123)$ terhadap keberadaan jentik vektor Chikungunya.
\end{abstract}

Kata kunci: PSN, jentik, vektor chikungunya

\section{Abstract}

Taratak Paneh is the most common area of Chikungunya cases in 2012 (45 cases).The spreading of Chikungunya is influenced by environmental factor and practice of breading place eradication. The objective of this study was to discover the relationship between breading place eradication practice and the presence of larvae Chikungunya vektor. This was an analytic research with cross-sectional study design. The research was held in Taratak Paneh on 87 samples. The samples were taken by proportional simple random sampling methods. Data were presented in distribution table and analyzed statistically with chi-square test. This study showed that there was relationship between breading place eradication practice and the presence of larvae Chikungunya vektor $(p=0,000)$. There is relationship between draining landfill $(p=0.029)$, covering landfill $(p=0,013)$, burying the junk $(p=0,034)$, sowing abate powder $(p=0.001)$, cleaning the gutter $(p=0,000)$ to the presence of larvae Chikungunya vektor. There is no relationship between maintain a larva-eating fish $(p=0,760)$, lighting and ventilation $(p=0.053)$, hang clothes in the room $(p=0.068)$, install wire gauze $(p=0.274)$, clean the pot/birdbath $(p=0.915)$, use of mosquito nets $(p=0.619)$, use of anti-mosquito drugs $(p=0.209)$ and cover the holes of trees $(p=0.123)$ to the presence of larvae Chikungunya vector. Keywords: breading place eradication practice, larvae, chikungunya vector

Affiliasi penulis :1. Prodi Profesi Dokter FK UNAND (Fakultas Kedokteran Universitas Andalas Padang), 2.Bagian Parasitologi FK UNAND, 3.Bagian Fisika FK UNAND

Korespondensi :Mutia Dwi Putri, Email :

mutiadwiputri_2104@yahoo.com, Telp: 085766391193

\section{PENDAHULUAN}

Chikungunya adalah suatu penyakit yang disebabkan oleh virus chikungunya dan ditularkan oleh 
Aedes aegypti dan Aedes albopictus. ${ }^{1}$ Gejala utama adalah demam mendadak, nyeri pada persendian dan kumpulan bintik-bintik kemerahan. ${ }^{2}$

Virus ini bersifat "self limiting diseases" (sembuh dengan sendirinya) dan tidak menyebabkan kematian namun akan sangat mengganggu produktivitas penderitanya. Penyakit ini cenderung menimbulkan Kejadian Luar Biasa (KLB) pada sebuah wilayah. $^{3}$

Ada beberapa faktor yang memegang peranan dalam kemunculan penyakit Chikungunya yaitu virus Chikungunya sebagai agen penyakit, manusia sebagai inang dan Aedes spp. sebagai vektor penyakit. Keberadaan jentik Aedes spp. di suatu daerah merupakan indikator terdapatnya populasi nyamuk Aedes spp. dan berpengaruh terhadap kepadatan jentik di daerah tersebut. ${ }^{4}$

Kemunculan penyakit Chikungunya juga dipengaruhi oleh perilaku masyarakat setempat dan menentukan keterjangkitan suatu penyakit di tengah masyarakat. ${ }^{5}$ Untuk mengurangi penyebaran penyakit Chikungunya, maka perlu dilakukan tindakan pencegahan. Salah satu upaya pencegahan penyakit Chikungunya ialah pemutusan rantai vektor penularnya dengan cara Pemberantasan Sarang Nyamuk (PSN) yaitu kegiatan untuk memberantas jentik nyamuk di tempat perkembangbiakannya., ${ }^{2,5}$

PSN merupakan cara pemberantasan yang paling baik, lebih aman, murah dan sederhana yang dapat dilakukan oleh masyarakat. Keberhasilan PSN sangat tergantung pada peran serta masyarakat. PSN dilakukan dengan menerapkan program "3M-Plus". Program 3M yang dimaksud adalah Menguras, Menutup dan Mengubur barang bekas serta tempat yang bisa menampung air. Selain itu ditambah (plus) dengan menaburkan bubuk abate pada penampungan air, mengganti air vas bunga atau tempat lainnya yang sejenis seminggu sekali, memakai kelambu, memasang kawat kasa, tidak menggantung pakaian di kamar dan tindakan lainnya. ${ }^{5}$

Praktik PSN yang buruk adalah faktor resiko kejadian penyakit Chikungunya. ${ }^{6}$ Penelitian Dharma (2012) menunjukkan bahwa terdapat hubungan yang bermakna antara tindakan PSN dan keberadaan jentik dengan kejadian Chikungunya. ${ }^{7}$ Booroto (2012) menunjukkan bahwa terdapat hubungan yang bermakna antara tindakan PSN dengan keberadaan jentik Aedes spp. ${ }^{8}$ Triwinasis (2010) juga menunjukkan bahwa terdapat hubungan yang bermakna antara menguras dan menutup tempat penampungan air (TPA) dengan keberadaan jentik Aedes spp. Mengubur barang bekas tidak memiliki hubungan yang bermakna dengan keberadaan jentik Aedes spp. ${ }^{9}$

Hasil survei pendahuluan yang dilakukan di Kampung Taratak Paneh dengan mewawancarai 20 orang responden menunjukkan bahwa delapan orang tidak membersihkan atau menguras bak mandi minimal satu kali seminggu, sembilan orang tidak menutup tempat penampungan air, 14 orang tidak pernah menggunakan bubuk abate dan tidak ada responden yang memakai kelambu, memasang kawat kasa serta memelihara ikan pemakan jentik. Pada 12 orang responden ditemukan jentik dirumahnya dan sisanya 8 orang responden tidak ditemukan jentik. Secara keseluruhan, 14 orang responden memiliki tindakan PSN baik dan sisanya 6 orang memiliki tindakan PSN kurang baik. Berdasarkan survei pendahuluan tersebut maka dapat disimpulkan bahwa perilaku masyarakat dalam melaksanakan PSN Chikungunya di Kampung Taratak Paneh belum terwujud secara optimal dan lebih dari separuh responden terdapat jentik di rumahnya.

Penelitian ini dilakukan dengan tujuan untuk mengetahui hubungan tindakan PSN terhadap keberadaan jentik vektor Chikungunya di wilayah tersebut.

\section{METODE}

Jenis penelitian adalah analitik observasional dengan desain cross sectional study. Populasi penelitian adalah semua Kepala Keluarga (KK) di Kampung Taratak Paneh. Sampel berjumlah 87 KK yang dipilih dengan metode Proporsional Simple

Random Sampling. Penelitian dilaksanakan dari bulan Maret - Mei 2014. Variabel terikat dalam penelitian ini adalah keberadaan jentik vektor Chikungunya. Variabel bebas dalam penelitian ini adalah tindakan Pemberantasan Sarang Nyamuk (PSN). Pengumpulan 
data dilakukan dengan cara wawancara dan observasi langsung di rumah responden. Uji statistik menggunakan chi-square.

\section{HASIL}

tabel 1. Distribusi frekuensi keberadaan jentik vektor chikungunya berdasarkan rumah di Kampung Taratak Paneh

\begin{tabular}{lcc}
\hline Keberadaan Jentik & f & $\%$ \\
\hline Ada & 34 & 39,08 \\
Tidak Ada & 53 & 60,92 \\
\hline Jumlah & 87 & 100 \\
\hline
\end{tabular}

Tabel 1 menunjukkan 87 rumah yang diperiksa, sebanyak 53 rumah $(60,92 \%)$ tidak ditemukan adanya jentik dan sisanya sebanyak 34 rumah (39,08\%) ditemukan jentik, sehingga diperoleh Angka Bebas Jentik (ABJ) sebesar 60,92\%.

Tabel 2. Distribusi frekuensi kepadatan jentik vektor chikungunya per Rukun Tetangga (RT) berdasarkan House Index $(\mathrm{HI})$, Container Index $(\mathrm{Cl})$ dan Breteau Index (BI) di Kampung Taratak Paneh berdasarkan RT

\begin{tabular}{cccccccc}
\hline RT & $\begin{array}{c}\text { HI } \\
(\%)\end{array}$ & DF & $\begin{array}{c}\text { Cl } \\
(\%)\end{array}$ & DF & $\begin{array}{c}\text { BI } \\
(\%)\end{array}$ & $\begin{array}{c}\text { DF } \\
\text { Rata- } \\
\text { rata }\end{array}$ \\
\hline RT 1 & 14,28 & 3 & 6,67 & 3 & 14,28 & 3 & 3 \\
RT 2 & 63,16 & 8 & 35,00 & 8 & 73,68 & 6 & 7,33 \\
RT 3 & 57,89 & 7 & 37,50 & 8 & 78,94 & 7 & 7,33 \\
RT 4 & 20,00 & 4 & 10,00 & 4 & 20,00 & 4 & 4 \\
RT 5 & 30,00 & 5 & 15,38 & 5 & 40,00 & 5 & 5 \\
\hline $\begin{array}{c}\text { Rata- } \\
\text { rata }\end{array}$ & 39,08 & 6 & 21,87 & 6 & 48,27 & 5 & 5,7 \\
\hline
\end{tabular}

Tabel 2 memperlihatkan bahwa kepadatan vektor Chikungunya di Kampung Taratak Paneh berdasarkan House Index $(\mathrm{HI})$ yaitu $39,08 \%$, dengan angka tertinggi di RT 2 (63,16\%) dan terendah di RT 1 (14,28\%). Angka Container Index (Cl) diperoleh $21,87 \%$, dengan angka tertinggi di RT 3 (37,50\%) dan terendah di RT 1 (6,67\%). Angka untuk Breteau Index (BI) yaitu 48,27\%, angka tertinggi di RT 3 (78,94\%) dan terendah di RT 1 (14,28\%). Angka Density Figure (DF) yang didapatkan di Kampung Taratak Paneh yaitu 5,7, dimana angka tertinggi berada di RT 2 dan RT 3 yaitu sama-sama 7,33 dan terendah ditemukan di RT 1 yaitu sebesar 3 .

Tabel 3. Distribusi frekuensi jenis dan letak kontainer berdasarkan keberadaan jentik vektor chikungunya di Kampung Taratak Paneh

\begin{tabular}{|c|c|c|c|c|}
\hline \multirow[b]{2}{*}{ Kontainer } & \multicolumn{4}{|c|}{ Jumlah } \\
\hline & f & $\%$ & $\begin{array}{c}(+) \\
\text { Jentik }\end{array}$ & $\%$ \\
\hline Dalam rumah & 147 & 76,56 & 31 & 16,15 \\
\hline 1.Bak Mandi Keramik & 26 & 13,54 & 7 & 3,64 \\
\hline 2.Bak Mandi Semen & 34 & 17,70 & 14 & 7,28 \\
\hline 3. Drum & 3 & 1,56 & 0 & 0 \\
\hline 4. Baskom & 13 & 6,77 & 3 & 1,56 \\
\hline 5. Sumur & 6 & 3,12 & 0 & 0 \\
\hline 6. Akuarium & 3 & 1,57 & 0 & 0 \\
\hline 7.Dispenser & 24 & 12,5 & 2 & 1,04 \\
\hline 8. Tandon Kulkas & 18 & 9,38 & 1 & 0,52 \\
\hline 9. Ember & 20 & 10,42 & 4 & 2,08 \\
\hline Luar Rumah & 45 & 23,44 & 11 & 5,72 \\
\hline 1. Kaleng Bekas & 7 & 2,61 & 3 & 1,56 \\
\hline 2. Ban Bekas & 1 & 1,04 & 0 & 0 \\
\hline 3. Ember Bekas & 3 & 1,56 & 0 & 0,52 \\
\hline 4. Drum & 3 & 1,04 & 1 & 0,52 \\
\hline $\begin{array}{l}\text { 5. Tempat Minum } \\
\text { Burung }\end{array}$ & 4 & 2,61 & 0 & 0 \\
\hline 6. Kolam & 1 & 1,04 & 0 & 0 \\
\hline $\begin{array}{l}\text { 7. Pot Bunga Berisi } \\
\text { Air }\end{array}$ & 3 & 2,08 & 1 & 0,52 \\
\hline 8. Baskom & 5 & 1,04 & 2 & 1,04 \\
\hline 9. Bak & 3 & 1,04 & 1 & 0.52 \\
\hline $\begin{array}{l}\text { 10. Tempurung } \\
\text { Kelapa }\end{array}$ & 3 & 2,08 & 1 & 0,52 \\
\hline 11. Plastik Bekas & 2 & 1,04 & 0 & 0 \\
\hline $\begin{array}{l}\text { 12. Bekas Adonan } \\
\text { Semen }\end{array}$ & 1 & 0,52 & 0 & 0 \\
\hline 13. Lesung & 1 & 1,04 & 0 & 0 \\
\hline 14. Lubang Pohon & 3 & 1,56 & 0 & 0 \\
\hline 15. Genangan Air & 2 & 1,04 & 0 & 0 \\
\hline 16. Talang Air & 2 & 1,04 & 0 & 0 \\
\hline $\begin{array}{l}\text { 17. Penampungan } \\
\text { Air Limbah }\end{array}$ & 2 & 1,04 & 1 & 0,52 \\
\hline Jumlah & 192 & 100 & 42 & 21,87 \\
\hline
\end{tabular}

Berdasarkan Tabel 3 diketahui bahwa jentik Aedes spp. lebih menyukai kontainer yang berada di dalam rumah dibandingkan di luar rumah. Hal ini terlihat dari kontainer di dalam rumah yang positif jentik sebanyak 31 kontainer $(16,15 \%)$ sedangkan 
kontainer yang berada di luar rumah dan positif jentik sebanyak 11 kontainer (5,72\%). Kontainer di dalam rumah yang terbanyak mengandung jentik Aedes spp. adalah bak mandi semen yaitu sebanyak 14 buah (7,28\%), kemudian diikuti bak mandi keramik sebanyak 7 buah (3,64\%). Kontainer di luar rumah yang terbanyak mengandung jentik adalah kaleng bekas, yaitu sebanyak 3 buah (1,56\%).

Tabel 4. Jenis vektor chikungunya perRT berdasarkan letak kontainer di Kampung Taratak Paneh

\begin{tabular}{|c|c|c|c|c|c|c|c|c|}
\hline \multirow{3}{*}{$\begin{array}{c}\text { Letak } \\
\text { Kontainer }\end{array}$} & \multicolumn{4}{|c|}{ Dalam Rumah } & \multicolumn{4}{|c|}{ Luar Rumah } \\
\hline & \multicolumn{2}{|c|}{$\begin{array}{c}\text { Ae. } \\
\text { aegypti }\end{array}$} & \multicolumn{2}{|c|}{$\begin{array}{c}\text { Ae. } \\
\text { albopictus }\end{array}$} & \multicolumn{2}{|c|}{$\begin{array}{c}\text { Ae. } \\
\text { aegypti }\end{array}$} & \multicolumn{2}{|c|}{$\begin{array}{c}\text { Ae. } \\
\text { albopictus }\end{array}$} \\
\hline & $f$ & $\%$ & $f$ & $\%$ & $f$ & $\%$ & $f$ & $\%$ \\
\hline RT 1 & 2 & 4,76 & 0 & 0.00 & 0 & 0.00 & 0 & 0.00 \\
\hline RT 2 & 11 & 26,19 & 0 & 0.00 & 1 & 2,38 & 2 & 4,76 \\
\hline RT 3 & 10 & 23,80 & 0 & 0.00 & 1 & 2,38 & 4 & 9,52 \\
\hline RT 4 & 3 & 7,14 & 0 & 0.00 & 0 & 0.00 & 0 & 0.00 \\
\hline RT 5 & 5 & 11,91 & 0 & 0.00 & 2 & 4,76 & 1 & 2,38 \\
\hline Jumlah & 31 & 73,81 & 0 & 0.00 & 4 & 9,52 & 7 & 16,67 \\
\hline
\end{tabular}

Tabel 4 menunjukkan bahwa jenis jentik yang paling banyak ditemukan adalah jentik Ae. aegypti (83,33\%), sedangkan jentik Ae. albopictus ditemukan sebanyak (16,67\%). Jentik nyamuk ditemukan terbanyak di RT $3(35,70 \%)$ dan paling sedikit ditemukan di RT 1 (4,76\%). Berdasarkan letak kontainer diketahui bahwa jentik Ae. aegypti paling banyak ditemukan di dalam rumah (73,81\%) dibandingkan di luar rumah $(9,52 \%)$, sedangkan jentik Ae. albopictus hanya ditemukan di luar rumah. Berdasarkan lokasi, di dalam rumah terlihat jentik Ae. aegypti ditemukan terbanyak di RT 2 (26,19\%) dan paling sedikit ditemukan di RT 1 (4,76\%), sedangkan Ae. albopictus tidak ditemukan di dalam rumah. Di luar rumah, jentik Ae. aegypti ditemukan terbanyak di RT 5 $(4,76 \%)$ dan paling sedikit ditemukan di RT 1 dan RT 2 $(0,00 \%)$. Jentik Ae. albopictus ditemukan terbanyak di RT 3 (9,52\%) dan paling sedikit ditemukan di RT 1 dan RT 4 (0,00\%).

Tabel 5. Distribusi frekuensi jenis tindakan PSN berdasarkan RT di Kampung Taratak Paneh

\begin{tabular}{lllllll}
\hline \multirow{2}{*}{ RT } & \multicolumn{2}{l}{ Kurang Baik } & \multicolumn{2}{l}{ Baik } & \multicolumn{3}{l}{ Jumlah } \\
\cline { 2 - 7 } & $\mathbf{f}$ & $\%$ & $\mathbf{f}$ & $\%$ & $\mathbf{f}$ & $\%$ \\
\hline RT1 & 5 & 35,72 & 9 & 64,28 & 14 & 100 \\
RT2 & 9 & 47,37 & 10 & 52,63 & 19 & 100 \\
RT3 & 10 & 52,63 & 9 & 47,37 & 19 & 100 \\
RT4 & 7 & 46,67 & 8 & 53,33 & 15 & 100 \\
RT5 & 8 & 40,00 & 12 & 60,00 & 20 & 100 \\
\hline Jumlah & 39 & 44,83 & 48 & 55,17 & 87 & 100 \\
\hline
\end{tabular}

Tabel 5 memperlihatkan bahwa sebagian besar masyarakat Kampung Taratak Paneh memiliki tindakan PSN baik (55,17\%). Berdasarkan RT, RT 3 memiliki tindakan PSN kurang baik tertinggi (52,63\%) dan tertendah oleh RT 1 (35,72\%).

Tabel 6. Distribusi frekuensi jenis tindakan PSN berdasarkan 3M Plus di Kampung Taratak Paneh

\begin{tabular}{|c|c|c|c|c|}
\hline \multirow{3}{*}{ Tindakan PSN } & \multicolumn{4}{|c|}{ Dilakukan } \\
\hline & \multicolumn{2}{|c|}{ Tidak } & \multicolumn{2}{|c|}{ Ya } \\
\hline & $f$ & $\%$ & $f$ & $\%$ \\
\hline $\begin{array}{l}\text { 1. Menguras TPA } \\
\text { keperluan mandi }\end{array}$ & 18 & 20,69 & 69 & 79,31 \\
\hline $\begin{array}{l}\text { 2. Menutup dengan rapat } \\
\text { TPA }\end{array}$ & 47 & 54,02 & 40 & 45,98 \\
\hline $\begin{array}{l}\text { 3. Mengubur barang } \\
\text { bekas }\end{array}$ & 16 & 18,39 & 71 & 81,61 \\
\hline 4. Menabur bubuk abate & 62 & 71,26 & 25 & 28,74 \\
\hline $\begin{array}{l}\text { 5. Memeliharaikan } \\
\text { pemakanJentik }\end{array}$ & 68 & 78,16 & 19 & 21,84 \\
\hline $\begin{array}{l}\text { 6. Menggantung pakaian } \\
\text { didalam kamar }\end{array}$ & 15 & 17,24 & 72 & 82,76 \\
\hline 7. Memasang kawat kasa & 9 & 10,34 & 78 & 89,66 \\
\hline $\begin{array}{l}\text { 8. Membersihkanpot/vas } \\
\text { bunga berisi } \\
\text { air,tempat minum } \\
\text { burung }\end{array}$ & 66 & 75,86 & 21 & 24,14 \\
\hline 9. Menggunakan kelambu & 28 & 32,18 & 59 & 67,82 \\
\hline $\begin{array}{l}\text { 10. Menggunakan obat } \\
\text { anti nyamuk }\end{array}$ & 1 & 1,15 & 86 & 98,85 \\
\hline 11. Menutuplubangpohon & 83 & 95,40 & 4 & 4,60 \\
\hline
\end{tabular}

Berdasarkan Tabel 6 dapat dilihat bahwa tindakan PSN yang paling banyak dilakukan adalah memakai obat anti nyamuk (98,85\%) dan yang paling sedikit adalah menutup lubang pohon/potongan bambu $(4,60 \%)$. 
Tabel 7. Hubungan tindakan PSN dengan keberadaan jentik vektor chikungunya di Kampung Taratak Paneh

\begin{tabular}{|c|c|c|c|c|c|}
\hline \multirow{3}{*}{$\begin{array}{c}\text { Tindakan } \\
\text { PSN }\end{array}$} & \multicolumn{4}{|c|}{ Keberadaan Jentik } & \multirow{3}{*}{$\mathbf{p}$} \\
\hline & \multicolumn{2}{|c|}{ Ada } & \multicolumn{2}{|c|}{ Tidak ada } & \\
\hline & $f$ & $\%$ & $f$ & $\%$ & \\
\hline $\begin{array}{l}\text { Kurang } \\
\text { Baik }\end{array}$ & 24 & 61,54 & 15 & 38,46 & 0,000 \\
\hline Baik & 10 & 20,83 & 38 & 79,17 & \\
\hline Jumlah & 34 & 39,08 & 53 & 60,92 & \\
\hline
\end{tabular}

Pada Tabel 7 dapat dilihat bahwa tindakan responden dengan kategori kurang baik dan terdapat jentik di rumahnya adalah sebesar 61,54\%, sedangkan tindakan responden kategori baik dan terdapat jentik di rumahnya yaitu sebesar 20,83\%. Hasil uji statistik didapatkan nilai $p=0,000$. Hal ini menunjukkan bahwa terdapat hubungan yang bermakna antara tindakan PSN responden dengan keberadaan jentik vektor Chikungunya.

Tabel 8a. Hubungan tindakan PSN menurut 3M Plus dengan keberadaan jentik vektor chikungunya di Kampung Taratak Paneh

\begin{tabular}{|c|c|c|c|c|c|c|}
\hline \multirow{3}{*}{ 3MP } & \multirow{3}{*}{$\begin{array}{c}\text { Tindakan } \\
\text { PSN }\end{array}$} & \multicolumn{4}{|c|}{ Keberadaan Jentik } & \multirow{3}{*}{ p } \\
\hline & & \multicolumn{2}{|c|}{ Ada } & \multicolumn{2}{|c|}{ Tidak ada } & \\
\hline & & $f$ & $\%$ & $f$ & $\%$ & \\
\hline \multirow{2}{*}{ P1 } & Tidak & 4 & 19,0 & 17 & 81,0 & \multirow{2}{*}{0,031} \\
\hline & Ya & 30 & 45,5 & 36 & 54,5 & \\
\hline \multirow{2}{*}{ P2 } & Tidak & 3 & 16,7 & 15 & 83,3 & \multirow{2}{*}{0,029} \\
\hline & Ya & 31 & 44,9 & 38 & 55,1 & \\
\hline \multirow{2}{*}{ P3 } & Tidak & 2 & 14,3 & 12 & 85,7 & \multirow{2}{*}{0,038} \\
\hline & Ya & 32 & 43,8 & 41 & 56,2 & \\
\hline \multirow{2}{*}{ P4 } & Tidak & 24 & 51,1 & 23 & 48,9 & \multirow{2}{*}{0,013} \\
\hline & Ya & 10 & 25,0 & 30 & 75,0 & \\
\hline \multirow{2}{*}{ P5 } & Tidak & 10 & 62,5 & 6 & 37,5 & \multirow{2}{*}{0,034} \\
\hline & Ya & 24 & 33,8 & 47 & 66,2 & \\
\hline \multirow{2}{*}{ P6 } & Tidak & 31 & 50,0 & 31 & 50,0 & \multirow{2}{*}{0,001} \\
\hline & Ya & 3 & 12,0 & 22 & 88,0 & \\
\hline \multirow{2}{*}{ P7 } & Tidak & 26 & 38,2 & 42 & 61,8 & \multirow{2}{*}{0,760} \\
\hline & Ya & 8 & 42,1 & 11 & 57,9 & \\
\hline
\end{tabular}

Tabel 8b. Hubungan tindakan PSN menurut 3M Plus dengan keberadaan jentik vektor chikungunya di Kampung Taratak Paneh

\begin{tabular}{|c|c|c|c|c|c|c|c|}
\hline \multirow{3}{*}{ 3MP } & \multirow{3}{*}{$\begin{array}{c}\text { Tindakan } \\
\text { PSN }\end{array}$} & \multicolumn{4}{|c|}{ Keberadaan Jentik } & \multirow[b]{3}{*}{$\%$} & \multirow[b]{3}{*}{$p$} \\
\hline & & \multicolumn{2}{|c|}{ Ada } & \multicolumn{2}{|c|}{ Tidak ada } & & \\
\hline & & $f$ & $\%$ & $f$ & $\%$ & & \\
\hline \multirow[b]{2}{*}{ P8 } & Tidak & 4 & 80,0 & 1 & 20,0 & 5 & \multirow{2}{*}{0,053} \\
\hline & Ya & 30 & 36,6 & 52 & 63,4 & 100 & \\
\hline \multirow{2}{*}{ P9 } & Tidak & 9 & 60,0 & 6 & 40,0 & 100 & \multirow{2}{*}{0,068} \\
\hline & Ya & 25 & 34,7 & 47 & 65,3 & 100 & \\
\hline \multirow{2}{*}{ P10 } & Tidak & 2 & 22,2 & 7 & 77,8 & 100 & \multirow{2}{*}{0,274} \\
\hline & Ya & 32 & 41,0 & 46 & 59,0 & 100 & \\
\hline \multirow{2}{*}{ P11 } & Tidak & 26 & 39,4 & 40 & 60,6 & 100 & \multirow{2}{*}{0,915} \\
\hline & Ya & 8 & 38,1 & 13 & 61,9 & 100 & \\
\hline \multirow{2}{*}{ P12 } & Tidak & 12 & 42,9 & 16 & 57,1 & 100 & \multirow{2}{*}{0,619} \\
\hline & Ya & 22 & 37,3 & 37 & 62,7 & 100 & \\
\hline \multirow[t]{2}{*}{ P13 } & Tidak & 1 & $\begin{array}{c}100 \\
0\end{array}$ & 0 & 00,0 & 100 & \multirow[t]{2}{*}{0,209} \\
\hline & Ya & 33 & 38,4 & 53 & 61,6 & 100 & \\
\hline \multirow{2}{*}{ P14 } & Tidak & 23 & 60,5 & 15 & 39,5 & 100 & \multirow{2}{*}{0,000} \\
\hline & Ya & 11 & 22,4 & 38 & 77,6 & 100 & \\
\hline \multirow{2}{*}{ P15 } & Tidak & 31 & 36,6 & 52 & 63,4 & 100 & \multirow{2}{*}{0,123} \\
\hline & Ya & 3 & 75,0 & 1 & 25,0 & 100 & \\
\hline
\end{tabular}

Tabel 8 memperlihatkan bahwa tindakan PSN responden yang terbanyak tidak dilakukan dan terdapat jentik dirumahnya adalah menabur bubuk abate $(50 \%)$ dan menutup lubang pohon/potongan bambu (36,6\%). Sedangkan, tindakan PSN yang terbanyak dilakukan dan positif jentik adalah menggunakan obat anti nyamuk (38,4\%) dan memasang kawat kasa (41,0\%). Hasil uji statistik menujukkan bahwa tindakan membersihkan rumah secara menyeluruh minimal seminggu sekali $(p=0,031)$, menguras TPA untuk keperluan mandi $(p=0,029)$ dan keperluan rumah tangga $(p=0,038)$, menutup TPA setiap kali digunakan $(p=0,013)$, mengubur barang bekas $(p=0,034)$, menabur bubuk abate $(p=0,001)$, dan memberisihkan talang air $(p=0,000)$ menunjukkan hubungan yang bermakna dengan keberadaan jentik vektor Chikungunya, dimana $p<0,05$. Sedangkan, tindakan memelihara ikan pemakan jentik $(p=0,760)$, pencahayaan dan ventilasi yang cukup ( $p=0,053)$, menggantung pakaian di dalam kamar $(p=0,068)$, memasang kawat kasa $(p=0,274)$, membersihkan pot atau vas bunga berisi 
Air / tempat minum burung $(p=0,915)$, menggunakan kelambu $(p=0,619)$, menggunakan obat anti nyamuk $(p=0,209)$, dan menutup lubang pohon $(p=0,123)$ menunjukkan tidak terdapat hubungan yang bermakna dengan keberadaan jentik vektor Chikungunya.

\section{PEMBAHASAN}

Hasil penelitian ini menunjukkan bahwa $A B J$ di Kampung Taratak Paneh sebesar 60,92 \%. Angka tersebut tergolong masih rendah dan menandakan bahwa kepadatan jentik masih tinggi. ${ }^{5}$ Tahun 2007, Respati dan Keman juga memberikan hasil yang sama yaitu ABJ sebesar 63\%. Salah satu penyebab rendahnya nilai $A B J$ adalah kurangnya kesadaran masyarakat dalam membersihkan TPA yang berada di rumah. ${ }^{10} \mathrm{ABJ}$ yang rendah menggambarkan kondisi banyaknya tempat perindukan (breeding place) nyamuk Aedes spp sehingga memperbesar potensi terjadinya penyebaran nyamuk dan penularan Chikungunya. ${ }^{5} \mathrm{Hal}$ ini juga berhubungan dengan pemukiman di Kampung Taratak Paneh yang cukup padat dan jarak dari rumah ke rumah tidak begitu jauh sehingga memudahkan nyamuk berpindah dari satu rumah ke rumah lainnya. ${ }^{4}$

Rerata HI 39,08\%, Cl 21,87\%, BI 48,27\%, dan density figure rerata sebesar 5,7. Nilai ini menunjukkan bahwa kepadatan nyamuk di Kampung Taratak Paneh tergolong tinggi sehingga beresiko untuk terjadinya penularan penyakit Chikungunya. Menurut WHO (2005), daerah yang mempunyai HI lebih besar dari $5 \%$ dan $\mathrm{BI}$ lebih besar dari $20 \%$ memiliki resiko penularan kasus yang tinggi dan indikator adanya ancaman wabah Chikungunya apabila daerah dengan density figure diatas 5 , ini berarti besar sekali kemungkinan terjadinya transmisi penyakit Chikungunya, sedangkan apabila density figure $1-5$, maka kemungkinan transmisi penyakit Chikungunya dianggap rendah hingga sedang. ${ }^{12}$

Handayani (2007) memberikan hasil yang lebih rendah dengan nilai $\mathrm{HI}(25,86 \%), \mathrm{Cl}(12,17 \%)$ dan $\mathrm{BI}$ $(32,76 \%)$. Keadaan ini dapat disebabkan karena pemukiman di Kampung Taratak Paneh yang cukup padat dan jarak dari rumah ke rumah tidak begitu jauh sehingga memudahkan nyamuk berpindah dari satu rumah ke rumah lainnya. ${ }^{13}$ Ketinggian daerah tempat tinggal merupakan faktor penting yang membatasi penyebaran Ae. spp pada dataran rendah (kurang dari 500 meter) tingkat populasi nyamuk berkisar sedang hingga tinggi, sementara di daerah pegunungan populasinya lebih rendah. ${ }^{1}$

Hasil penelitian ini juga memperlihatkan bahwa jentik vektor Chikungunya lebih menyukai kontainer yang berada di dalam rumah dibandingkan di luar rumah. Hal ini terlihat dari kontainer di dalam rumah yang positif jentik 16,15\% sedangkan kontainer yang berada di luar rumah dan positif jentik 5,72\%. Tahun 2013, Wahyudi dan Ginanjar juga menunjukkan hal yang sama, kontainer yang terletak di dalam rumah dan positif jentik 20,57 \% sedangkan kontainer di luar rumah dan positif jentik 6,85 \%. ${ }^{14} \mathrm{Hal}$ ini terjadi karena di dalam rumah banyak terdapat tempat yang kondusif bagi vektor Chikungunya untuk berkembang. Adanya tempat penampungan air yang digunakan berkaitan dengan kegiatan sehari-hari seperti memasak, mencuci dan mandi umumnya lebih banyak berada di dalam rumah. ${ }^{5}$

Hasil penelitian ini juga memperlihatkan bahwa kontainer di dalam rumah yang terbanyak mengandung jentik vektor Chikungunya adalah bak mandi (10,92 \%). Permadi (2013) dalam penelitiannya juga memberikan hasil yang sama bahwa jenis kontainer yang paling banyak ditemukan positif jentik adalah bak mandi $(77,1 \%){ }^{15} \mathrm{Hal}$ ini disebabkan kebiasaan masyarakat terutama masyarakat Asia yang lebih senang mandi dengan menggunakan gayung daripada shower. ${ }^{12}$ Bak mandi merupakan tempat berukuran besar, sehingga kapasitas menampung air lebih banyak dan air tersebut biasanya berada cukup lama di dalamnya. Keadaan ini sangat potensial bagi nyamuk untuk berkembang biak. Selain itu, bak mandi pada umumnya merupakan kontainer yang terbuka atau jarang ditutup, sehingga memudahkan nyamuk Ae. Spp meletakkan telurnya. ${ }^{4,5}$

Penelitian ini memperlihatkan bahwa terdapat dua spesies vektor Chikungunya yang ditemukan di Kampung Taratak Paneh, yaitu Ae. aegypti dan Ae. albopictus. Jentik nyamuk Aedes aegypti lebih banyak ditemukan $(83,33 \%)$ dibandingkan jentik $\mathrm{Ae}$. 
albopictus (16,67\%). Jentik Ae. aegypti paling banyak ditemukan di dalam rumah (73,80\%) dibandingkan di luar rumah (9,53\%). Hal ini disebabkan tempat perkembangbiakan utama nyamuk $A e$. aegypti ialah tempat penampungan air buatan manusia dan berada di dalam rumah, biasanya terlindung dari sinar matahari dan berisi air bersih. ${ }^{5}$

Penelitian Wuryanto (2009) memperlihatkan bahwa Ae. aegypti tidak hanya berkembangbiak di tempat penampungan air dalam rumah dan berisi air bersih, tetapi juga mampu berkembangbiak di luar rumah dan berisi air kotor seperti selokan dan sumur galian. Dimana jumlah jentik dan pupa yang ditemukan tidak jauh berbeda dari yang ditemukan di tempat penampungan air bersih. ${ }^{16}$ Sementara itu, jentik $A e$. albopictus hanya ditemukan di luar rumah. Tahun 2007, Handayani juga memberikan hasil yang sama, seluruh jentik $A e$. albopictus yang ditemukan berada di luar rumah. Hal ini disebabkan karena Ae. albopictus lebih menyenangi tempat perindukan di luar rumah seperti kaleng bekas, lubang pohon, lekukan tanaman, potongan bambu dan tempurung kelapa. ${ }^{13}$

Hasil penelitian ini menunjukkan bahwa sebagian besar tindakan PSN di Kampung Taratak Paneh adalah baik (55,17\%). Meskipun sebahagian besar pelaksanaan PSN termasuk dalam kategori baik, akan tetapi masih terdapat responden yang berada dalam kategori kurang baik. Hal ini dapat berdampak pada semakin banyaknya TPA yang berpotensi menjadi tempat perindukan nyamuk sehingga dapat meningkatkan terjadinya kasus Chikungunya. ${ }^{5}$ Tindakan PSN yang masih kurang baik menunjukkan bahwa masih kurangnya kesadaran masyarakat terhadap pentingnya menjaga kebersihan rumah dan lingkungan sekitar tempat tinggal agar dapat mencegah terjadinya penyakit Chikungunya. ${ }^{2,17}$ Pelaksanaan PSN secara teratur dapat menghilangkan tempat penampungan air yang akan menjadi tempat perkembangbiakan nyamuk stadium jentik. Bila tempat perkembangbiakannya sudah tidak ada lagi maka jentik nyamuk Aedes. spp tidak dapat hidup dan masyarakat dapat memutus siklus hidup nyamuk Ae. Spp, sehingga dapat mencegah terjadinya penyakit Chikungunya. ${ }^{5,17}$
Hasil penelitian ini menunjukkan bahwa tindakan PSN yang paling banyak dilakukan adalah memakai obat anti nyamuk (98,85\%), sedangkan yang paling sedikit adalah menutup lubang pohon/potongan bambu (4,60\%). Mardihusodo (2009) memberikan hasil yang sama, yaitu penggunaan obat anti nyamuk merupakan tindakan 3M Plus yang paling banyak dilakukan oleh masyarakat Banyumanik (83,68\%). ${ }^{18}$ $\mathrm{Hal}$ ini berkaitan bahwa penggunaan obat anti nyamuk merupakan alternatif terbaik bagi masyarakat untuk terhindar dari gigitan nyamuk. Padahal penggunaan obat anti nyamuk hanya menghindarkan masyarakat dari gigitan nyamuk dewasa sedangkan keberadaan jentik tetap akan bertambah selama keberadaan nyamuk dewasa masih ada dan berkembangbiak. ${ }^{5,12}$

Hasil penelitian ini juga memperlihatkan bahwa tindakan PSN responden yang paling banyak tidak dilakukan dan terdapat jentik dirumahnya adalah menabur bubuk abate (50\%) dan menutup lubang pohon/potongan bambu (36,6\%). Tindakan PSN yang paling banyak dilakukan dan positif jentik adalah menggunakan obat anti nyamuk (38,4\%) dan memasang kawat kasa (41,0\%). Kurangnya pengetahuan akan pentingnya bubuk abate ditabur di TPA merupakan penyebab utama semua rumah tidak menabur bubuk abate. Perlu adanya faktor pendukung atau suatu kondisi yang memungkinkan, sehingga responden mau melakukan abatisasi. ${ }^{6}$

Hasil uji statistik menunjukkan menabur bubuk abate memiliki hubungan dengan keberadaan jentik. Hal ini sejalan dengan penelitian Mardihusodo (2009) bahwa terdapat hubungan yang bermakna menabur bubuk abate dengan keberadaan jentik. ${ }^{18} \mathrm{Hal}$ ini juga berkaitan dengan responden masih merasa tidak aman untuk melakukan abatisasi karena air dalam TPA-nya akan menjadi kotor serta takut jika bubuk abate akan memberikan dampak negatif bagi kesehatan. Diperlukan upaya untuk memberikan informasi yang benar mengenai bubuk abate dan cara penggunaannya. Selain informasi/pengetahuan yang diberikan dari pihak puskesmas, adanya pembagian rutin bubuk abate setiap bulannya juga menjadi salah satu solusi untuk menciptakan koordinasi antara masyarakat dengan pihak terkait. $5,6,19$ 
Hasil uji statistik menunjukkan bahwa tindakan menguras TPA menunjukkan hubungan yang bermakna dengan keberadaan jentik vektor chikungunya. Penelitian Mustika (2013) juga menunjukkan terdapat hubungan menguras TPA dengan keberadaan jentik $(p=0,000) .{ }^{19}$ Meskipun demikian, hasil penelitian ini bertolak belakang dengan penelitian yang dilakukan oleh Widjaja (2011) yang menyatakan bahwa tidak ada hubungan antara menguras tempat penampungan air dalam rumah dengan keberadaan jentik Aedes spp. ${ }^{20}$ Menguras tempat penampungan air merupakan salah satu cara pencegahan penyakit Chikungunya, dengan cara membersihkan tempat perkembangbiakan nyamuk Ae. aegypti pencegahan ini lebih sering dilakukan di tingkat rumah tangga tetapi tidak menutup kemungkinan dapat dilakukan di perkantoran maupun tempat umum lainnya. Menguras TPA tersebut minimal sekali seminggu dapat mengurangi tempat perkembangbiakan jentik Ae. aegytpi. ${ }^{4,5}$

Menutup rapat TPA memegang peranan penting dalam pemberantasan sarang nyamuk. Hasil uji statistik menunjukkan bahwa menutup rapat TPA setiap kali digunakan memiliki hubungan yang bermakna dengan keberadaan jentik vektor Chikungunya. Penelitian ini sejalan dengan yang dilakukan oleh Mustika (2013) dengan nilai $p=0.002$, berarti ada hubungan antara menutup rapat tempat penampungan air (TPA) dengan keberadaan jentik Ae. aegypti. $^{19}$ Penelitian ini berbeda dengan yang dilakukan oleh Widjaja (2011), dimana tidak ada hubungan antara menutup rapat tempat penampungan air (TPA) dengan keberadaan jentik Ae. aegypti. ${ }^{20}$ Mayarakat Kampung Taratak Paneh lebih suka menampung air untuk keperluan sehari-hari di Tempat Penampungan Air (TPA) seperti: baskom, ember, gentong, dan tempayan. Sehingga nyamuk Ae. aegypti lebih suka menetaskan telurnya di TPA tersebut hingga menjadi jentik Ae. aegypti. Sehingga menutup rapat TPA sangat berperan penting dapat mengurangi jumlah jentik Ae. aegypti yang ada di dalam TPA. ${ }^{17}$

Mengubur barang bekas merupakan tindakan PSN dengan cara mengubur barang-barang bekas yang berpotensi menampung air dan terdapat jentik Aedes spp serta tidak dimanfaatkan lagi, seperti kaleng bekas, potongan bambu dan ban bekas. Hasil uji statistik menunjukkan bahwa mengubur barang bekas memiliki hubungan yang bermakna dengan keberadaan jentik vektor Chikungunya. Hasil penelitian ini sejalan dengan penelitian Mardihusodo (2009) yang menunjukkan bahwa terdapat hubungan yang bermakna antara mengubur barang bekas dengan keberadaan jentik. Hal ini disebabkan karena faktor perbedaan karakteristik masyarakat di masingmasing lokasi penelitian dan lahan kosong yang menunjang. ${ }^{18}$ Hasil penelitian ini tidak sejalan dengan penelitian yang dilakukan oleh Mustika (2013) yang menunjukkan bahwa tidak ada hubungan antara mengubur barang-barang bekas dengan keberadaan jentik Ae. aegypti. Hal ini disebabkan karena tidak mempunyai cukup ruang dan kurangnya lahan yang digunakan untuk mengubur barang-barang bekas serta padatnya penduduk. ${ }^{19}$

Tindakan PSN lainnya adalah memelihara ikan pemakan jentik dengan meletakkannya di TPA guna mengurangi jumlah jentik. Hasil uji statistik menunjukkan bahwa memelihara ikan pemakan jentik tidak memiliki hubungan yang bermakna dengan keberadaan jentik. Penelitian ini sejalan dengan penelitian yang dilakukan oleh Mustika (2013) yang menunjukkan bahwa memelihara ikan pemakan jentik tidak ada hubungan dengan keberadaan jentik, hal ini dikarenakan predator hanya sebagai beberapa faktor yang mempengaruhi keberadaan jentik bukan faktor utama ada tidaknya jentik Ae. aegypti. ${ }^{19}$

Selain itu, pencahayaan dan ventilasi yang cukup juga merupakan salah satu tindakan PSN. Hasil uji statistik menunjukkan tidak ada hubungan pencahayaan dan ventilasi yang cukup dengan keberadaan jentik. Hal ini tidak sejalan dengan penelitan Rumantora (2011), dimana pencahayaan dan ventilasi yang cukup memiliki hubungan yang bermakna dengan keberadaan jentik Aedes spp. Hal ini berkaitan dengan kondisi yang baik bagi nyamuk untuk berkembangbiak. Nyamuk Aedes spp. menyukai tempat gelap atau pencahayaan kurang serta lembab. ${ }^{6}$ 


\section{KESIMPULAN}

Tindakan PSN yang paling banyak dilakukan adalah memakai obat anti nyamuk dan yang paling sedikit adalah menutup lubang pohon/potongan bambu. Terdapat hubungan yang bermakna antara membersihkan rumah secara menyeluruh minimal seminggu sekali, menguras TPA, menutup TPA setiap kali digunakan, mengubur barang bekas, menabur bubuk abate, dan memberisihkan talang air dengan keberadaan jentik vektor Chikungunya.

Tindakan memelihara ikan pemakan jentik, pencahayaan dan ventilasi yang cukup, tidak menggantung pakaian di dalam kamar, memasang kawat kasa, membersihkan pot/vas bunga berisi air/tempat minum burung, menggunakan kelambu, menggunakan obat anti nyamuk dan menutup lubang pohon tidak memiliki hubungan yang bermakna dengan keberadaan jentik vektor Chikungunya.

\section{DAFTAR PUSTAKA}

1. Sembel DT. Nyamuk sebagai vektor penyakit pada manusia. Dalam: Entomologi Kedokteran. Yogyakarta: Andi Yogyakarta; 2010. hlm.48-73.

2. Widoyono. Chikungunya. Dalam: Penyakit tropis epidemiologi, penularan, pencegahan dan pemberantasannya. Edisi ke-2. Jakarta: Erlangga; 2010. hlm.81-6.

3. Anies. Seri lingkungan dan penyakit; manajemen berbasis lingkungan,solusi mencegah dan menanggulangi penyakit menular. Jakarta: Gramedia; 2006.

4. Boesri H. Biologi dan peranan Aedes albopictus (Skuse) 1894 sebagai penular penyakit. Aspirator. 2011;3(2):117-25.

5. Depkes RI. Pedoman pengendalian demam chikungunya. Edisi Ke-2. Jakarta: Ditjen P2PL; 2012.

6. Rumantora M,. Faktor-faktor yang berhubungan dengan kasus chikungunya pada kejadian luar biasa di Dusun Mentubang Desa Harapan Mulia Kabupaten Kayong Utara tahun 2010 (skripsi). Jakarta: Universitas Indonesia; 2011.

7. Dharma S. Hubungan keberadaan jentik aedes aegypti dan pelaksanaan 3M Plus dengan kejadian penyakit chikungunya di lingkungan XVIII Kelurahan Binjai Kota Medan tahun 2012 (skripsi).
Medan: Fakultas Kesehatan Masyarakat Universitas Sumatera Utara; 2012

8. Booroto AT . "The relationship between measures eradication mosquito nest with existence larvae mosquito Aedes spp. in environmental areas 1 teling atas village, district of Wanea Manado City". Makara Kesehatan. 2012;14(1): 16-21.

9. Triwinasis S. Hubungan antara praktik PSN dengan keberadaan jentik Aedes spp. di Kelurahan Keparakan (skripsi). Semarang: Universitas Diponegoro; 2010.

10. Respati Y, Keman S. Perilaku 3M, dan keberadaan jentik aedes spp. hubungannya dengan kejadian demam berdarah dengue. Jurnal Kesehatan Lingkungan. 2007;3(1).

11. Ridha R, Rahayu N. Hubungan kondisi lingkungan dan kontainer dengan keberadaan jentik nyamuk Aedes aegypti di Kota Banjarbaru. Jurnal Epidemiologi dan penyakit bersumber binatang. 2013;4(3):24-31.

12. WHO. Pencegahan dan pengendalian dengue dan demam berdarah dengue; panduan lengkap. Alih Bahasa: Widyastuti P. Jakarta: EGC; 2005.

13. Handayani I. Hubungan tindakan pencegahan demam berdarah dengue (DBD) dengan keberadaan larva vektor demam berdarah dengue di Kelurahan Aur Kuning Kota Bukittinggi (skripsi). Padang: Fakultas Kedokteran Universitas Andalas; 2007

14. Wahyudi RI, Ginanjar. Pengamatan keberadaan jentik aedes spp. pada tempat perkembangbiakan dan PSN di Kelurahan Ketapang". Jurnal Kesehatan Masyarakat. 2013;2 (2):23-9.

15. Permadi IG. Kontainer larva Aedes spp. di Desa Saung Naga Kabupaten Ogan Komering Ulu Sumatera Selatan tahun 2012. Jurnal Aspirator. 2013; 5(1):16-22.

16. Wuryanto AM. Aspek sosial dan lingkungan pada kejadian luar biasa (KLB) chikungunya (studi kasus KLB Chikungunya di Kelurahan Bulusan Kecamatan Tembalang Kota Semarang). Jurnal Promosi Kesehatan Indonesia. 2009;4(1):9-16.

17. Djakaria S, Saleha S. Vektor penyakit virus, riketsia, spiroketa dan bakteri. Dalam: Parasitologi kedokteran. Edisi Ke-4. Jakarta: Balai Penerbit FKUI; 2008. hlm.245-97. 
18. Mardihusodo JS. Pemilihan tempat bertelur nyamuk aedes aegypti pada air limbah rumah tangga di laboratorium. Jurnal Veteriner. 2009;10(4):205-7.

19. Mustika D. Hubungan antara praktik PSN dengan keberadaan jentik aedes spp. di Kelurahan
Keparakan (skripsi). Makassar: Universitas Hasanuddin; 2013.

20. Widjaja J. Keberadaan kontainer sebagai faktor resiko penularan demam berdarah dengue di Kota Palu, Sulawesi Tengah. Jurnal Aspirator. 2011; 3(2):82-8. 